\title{
同胞 2 名に舌下部甲状腺の認められた
}

\section{原発性甲状腺機能低下性侏儒症の 1 例}

\author{
東京大学医学部中尾内科（教授 中尾喜久） \\ 中尾喜久内村英正関原久彦 \\ 青木洋祐長滰重信鎮目和夫
}

\author{
A CASE OF DWARFISM DUE TO NON-GOITROUS \\ PRIMARY HYPOTHYROIDISM WITH SUBLINGUAL THYROID. \\ WHICH WAS ALSO OBSERVED IN TWO SISTERS \\ Kiku Nakao, Hidemasa Uchumura, Hisahiko Sekinara \\ Yosuke Aoki, Shigenobu Nagataki and Kazuo Shizume \\ The Third Department of Internal Medicine \\ Faculty of Medicine, University of Tokyo
}

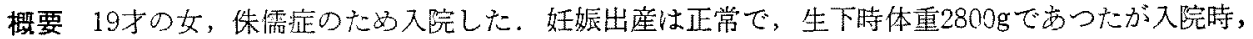
身長 $120.9 \mathrm{~cm}$ ，体重 $29 \mathrm{~kg}$ と 8 才相当であつた，学業成續は高校まで進み中等度で，IQは78であつ

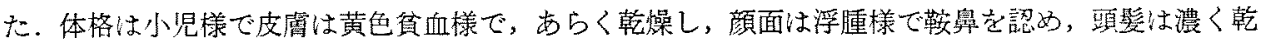

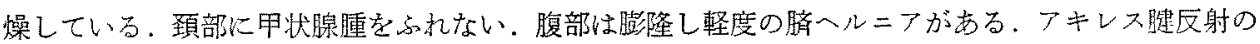
戻りがき和めて显い，検査所見は中等度の貧血，血清コレステロール高值を示し，さらにBMRは 暦年令で+3\%，身体年令でー20\%，骨年令では一 $25.5 \%$ であつたＰ B I $1.0 \gamma / \mathrm{dl} ，{ }^{131} \mathrm{I}$ uptake $2.4 \%$ ：シンチグラムは舌下部甲状腺を示した．T S Hに反応しなからた。他の内分泌学的検查は汪 注正常であつた。同胞 3 名中 2 名の峬は一卵性双生児であり, 双方に舌下部甲状腺を確かぬた。一方 の姉に精神障害を認め心。また本家系で全身性脱ヨート醉素の異常を思かせる所見を觉た。
\end{abstract}

甲状腺腫性クレチンと異なり非甲状腺腫性クレ チンが家族的に出現寸ることは，比較的稀なこと とされているが的，和われは，原因不明とされ るsporadic cretinismて，位置異常，家族的出現を 伴なら例，すなわち，原発性甲状腺機能低下によ る侏儒症で，その同胞 2 名に，患者之同様，甲状 腺シンチグラムにより，舌下部甲状腺を確認し， かつ一方に甲状腺機能の低下を認めた例を経験し た。同様の症例が今後も報告されれば，その原因 の究明の手がかりとなることと思う。

昭和41年12月 3 日 第181回関東地方会推萀
症例

T.T., 19才，女子.

主訴：侏儒症の精査.

既往歴：特記すべきことはない，

現病歴：妊娠出産時異常なく, 生下時体重は $2800 \mathrm{~g}$ と正常であつたが，以後歯牙萠出 1 年, 立上 り 1 年 3 力月, 歩行 1 年 6 力月と遅れる傾向を示 し， 7 才では正常身長 $114 \mathrm{~cm}$ に対して $98 \mathrm{~cm}$, 体重 は正常20kgに対して16.5kgであり，15才では 147 cmの正常值に対して $117 \mathrm{~cm}$, 体重は同に゙く38kgに 対して24.5kg と成長に徉って一層遈延傾向は顕著 
となつた．入院時の身長は $120.9 \mathrm{~cm}$, 体重は29.0 kgであつた，幼児のころから皮䖉は乾燥しがちで 発汗少なく、ざらざらしていたと言う。また出産 時から軞毛は多く，とくに背部に著明であり，頭 髮は濃くあらかつたと言う。

眼䀫はepicanthus様であつた。知能は乳幼児期 には同年月出生のものに比してやや発語等がおそ く, 就学後は, 中学までは中等度, 高校では中の 下の成績を収めている，3〜 4 年前から寒さに特 に敏感となつている. 現在まで, 月経は未だ認め られていない。また幼児期から食欲は正常であっ たが，摂取量は比較的少なく，便秘の傾向を示 し，3 日に 1 回位の排便しかなかつたとのことで ある。

\section{入院時主要所見}

体格は倭小で頭が大きく胸が太く，かつ下肢は 短い小児様である。

皮膚は黄色を帯び, やや貧血様で, 背部に生毛 が著明である，触れるとざらざらと荒く, 乾燥し ている，四肢伸側では表皮の落屃傾向を示してい る. 恥毛, 腋窩毛は認められない. 声は太く低音 である。

顔面は蒼白であり, 口唇は厚く浮腫様, puffy である、鞍鼻を示す. 頭髪は乾燥して濃く, 眼䀫 結膜は軽度の貧血を示しているが, 眼球結膜に黄 疸を認めない, 瞳孔正円, 対光反射は正常であっ た。眼底に異常はなかつた。、腔内に巨舌を認め ない、頝部は甲状腺腫をふれずまたリンパ節の 腫脹もなかつた。胸部では, 乳房の発達悪く, 肋 骨弓が下に開いている。心蔵の拡大はないが，心 尖部に軽度の収縮期雑音がきかれた。

肺野は正常肺胞音であつた。

腹部は著明に膨隆しており,きわめて軟らか く, 軽度の脐へルニアを認めた。肝は鎖骨中線で 1.5 横指ふれ, きわめて軟らかい. 脾, 腎はふれ なかつた、四肢に浮腫なく, 腱反射はアキレス腱 反射の戻りがきわめて遅い以外怔常であり, 病 的反射は認めなかつた。

脈拍68/分, 血圧96/72であつた。

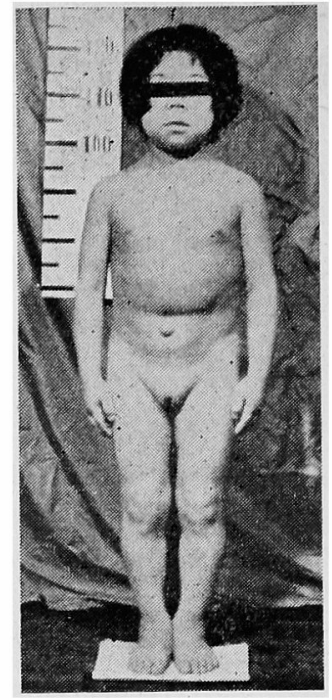

写真 1 . 患者

\section{入院後諸検查}

屎尿 ; 異常な乙. 血液; $\mathrm{Hb} 8.8 \mathrm{~g} / \mathrm{dl}$, 赤血球 $227 \times 10^{4}$, 白血球 4400 (桿状球 4.0 , 多核球 51.0 , 好 酸球 1.0 , 好塩球 0 , 単球 2.0 , リン八゚球 $42.0 \%$ ). 網状赤血球 $7 \%$, 血小板 $23.9 \times 10^{4}, \mathrm{Ht} 27 \%$. 血液 生化学 ; TP $8.4 \mathrm{~g} / \mathrm{dl}, \mathrm{A} / \mathrm{G} 1.1, \mathrm{Na} 138, \mathrm{~K} 3.9$, Cl 101, Ca 8.7, P 2.8, urea N 12.5, creatin$i^{\text {ne }} 0.7$, total cholesterol $262 \mathrm{mg} / \mathrm{dl}$, amylase 8 , creatine phosphokinase 9.1. 肝機能; MG6, alP-ase 3.0, T T T 4, ZnST 6, B S P (45分) $2.5 \%$, G O T 69, G P T 44. 腎機能 ; Fischberg 1020, P S P 15分 $25 \% 2$ 時間 $55 \%$, G F R 93， R P F 414, R B F 618, F F 0.224, 心電図 ; right ventricular preponderance.ベクトル心電図; within normal limits. 胸部X線写真; 異常なし. 血清フォレ 一ゼ ; TP 7.7, alb58.4, $\alpha$-gl6.6, $\beta$-gl14.4, $\gamma$-gl 20.6. 血清学的検査; A S L O 100以下, C R P (-), Wasserman R (-), Coomb's test $(-)$, RA $\mathrm{t}^{\text {est }}$ (一). 胃透視; 異常なし. 頭蓋X線写真; トル コ鞍等ずで正常. 身体計測; 身長 $120.5 \mathrm{~cm}$, 体 重 $28.2 \mathrm{~kg}$, 坐高 $71.3 \mathrm{~cm}$, 頭囲 $54.7 \mathrm{~cm}$, 比坐高 59.29 $\mathrm{cm}$ ( 8 才では $55.28 \mathrm{~cm}$ ), 躯幹に比して下肢が短か く，また頭が大きい所見で，8才に相当する。 


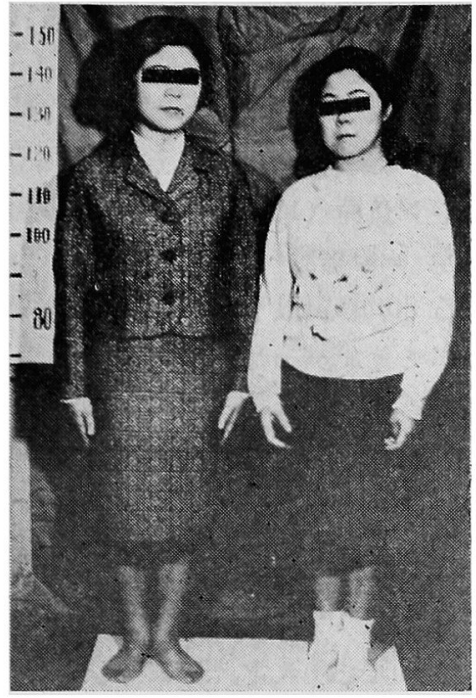

写真 2。2 名の㚲（左竝 A，右姉 B ）

骨年令；手根骨，橈骨，尺骨の骨端出現の程 度から 5 才に相当するものであつた。

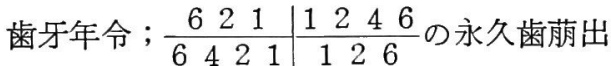

$\frac{\mathrm{EDC}}{\mathrm{C}} \mid \frac{\mathrm{C}}{\mathrm{CDE}}$ の乳歯残存, $\frac{7543}{753} \mid \frac{359}{3457}$ の永久歯歯牙埋伏を示し， 9 〜 10才相当のもので ある。

I Q（WA I S）； 78（字語性87, 動作性72）. 記銘力; 有関倸語 8-10-10, 無関係語 $2-5$ -7 .

ロールシャッハテスト； 反応数, 反応時間と もに正常, 把握力やや弱く自己中心傾向, 平板傾 向あり。とくに遅鈍は著明ではない。

脳波； basicに $7 \mathrm{c} / \mathrm{s}$ の slow alpha patternが認 められ，ときに孤立した 4 〜 $\mathrm{c} / \mathrm{s}$ の徐波を混入 するが，spike等は認めず，また左右差もない。

甲状腺機能；BMRは暦年令（19才）の計算 では+ $3 \%$ ，骨年令（5才）ではー $25.5 \%$ ，身体 年令 ( 8 才) ではー $20 \%$ ，歯牙年令（9才）では $-18 \%$. P B I $1.0 \mathrm{r} / \mathrm{dl}$. ${ }^{131}$ I uptake $2.4 \%$ (24 時間). $\mathrm{T}_{3}$ resin uptake $23.6 \%$. scintigram 舌下 部甲状腺を思わせるもの. T S H 負荷試験（チト ロパール10units，i.m投与) 前 $2.4 \%$, T S H 5 単位 2 日投与後の ${ }^{131}$ I uptake $3.7 \%$.

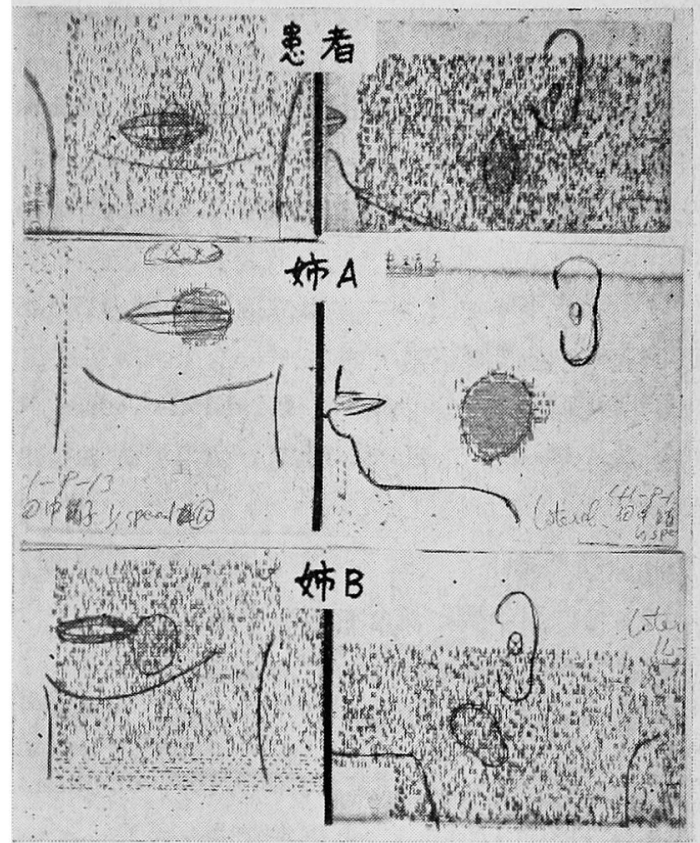

写真 3 . 患者と 2 名の姉たちの甲状腺シンチグラム

抗甲状腺抗体(抗サイログロブリン抗体)陰性. 耳鼻科的検査で, 舌根部に甲状腺を認なかかつた。

${ }^{131}$ I標識diiodotyrosine (D $\left.{ }^{131} \mathrm{IT}\right)$ 静注投与後の尿 中D ${ }^{131} \mathrm{IT}$ 排泄量； 1 時間 $14.5 \%$ ，2 時間 $7.1 \%$, 4 時間 $2.1 \%$ とほぼ正常值が得られた。

${ }^{131}$ 標識 thyroxine $\left(\mathrm{T}_{4}{ }^{131} \mathrm{I}\right)$ 静注投与後の $\mathrm{T}_{4}{ }^{131} \mathrm{I}$ 崩壊量（triiodothyronine $30 \gamma /$ day 投与中)， $\mathrm{T}^{1} / 2$ 3.5日. daily volume turn over $2.2 l /$ day. $\mathrm{T}_{4}$ degradation rate $22 \gamma /$ day. その他の内分泌学的検 査； growth hormone 早朝空腹時 $4.0,3.5 \mathrm{~m} \mu \mathrm{g}$ / ml とほぼ正常である。

Regular insulin 3 単位投与後のGHの変動， 30 分 $2.1 \mathrm{~m} \mu \mathrm{g} / \mathrm{ml}, 60$ 分 $9.0,90$ 分 7.5 , 著明な上昇は ないが，反応は認められる。少なくとも pituitary dwarfismは否定できる。

メトロピンテスト; 前 $2.2 \mathrm{mg} /$ day (urine 17OHCS) 1 日 $4.2 ， 2$ 日13.4.

A C THテスト（ $\beta^{1-24} \mathrm{ACTH}-\mathrm{Z} 50 \gamma$ i.m $)$; 前 $1.2 \mathrm{mg} /$ day (urine 17-OHCS), 1 日11.6, 2 日64.0.

Rapid ACTHテスト ( 250 r, i.v) ; 前 7.2 
$\gamma / \mathrm{dl}$ (plasma cortisol) 30分33.1，60分42.0等, 以上いずれも正常に近い反応を示している。

Dexamethasone $2 \mathrm{mg}$ 静注投与後のplasma cortisol の変動.

前 $9.5 \gamma / \mathrm{dl} ， 30$ 分 5.6，2 時間 5.8 とcortisolの degradationの延長がみとめられた。

尿中ゴナドトロピン 4 単位以下，尿中17-KS

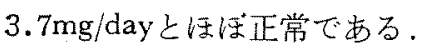

副甲状腺機能；血清Ca, P, al-P-ase, urea N 等正常, 燐クリアランス 10.7 , 燐再吸収率 85.3 $\%$.

$\mathrm{Ca}$ 負荷テスト;

第 1 日目尿中燐<第 2 日目尿中燐.

第2 日目血浆燐第 1 日目血燃燐。

副甲状腺機能のいちじるしい障害はない。

糖負荷試験； 前 $87 \mathrm{mg} / \mathrm{dl} ， 30$ 分 $167 ， 60$ 分 124 ， 2 時間 119，3 時間 114 と正常な曲線を描いてい る.

血液学的検查; 血清鉄 $49 \gamma / \mathrm{dl}$, 総鉄 結 合能 407, 不飽和鉄結合能 358 ，飽和率 $12.1 \%$ 之鉄欠乏 性貧血を思わせ敌所見，骨䯣穿刺所見，細胞数正
常, 盛んな赤芽球の增殖が認められた，鉄染色で はsideroblastを認めなかつた。

胃液酸度曲線は無酸症であつたがヒスタミンに よく反応し，総酸度は60まで上昇している。

ヒスチシン負荷（15g 経口）後の尿中formiminoglutamic acid排泄 (Tabor and Wyngardenの 方法による $30 \mu \mathrm{g} / \mathrm{ml}$ 以下で)，葉酸代謝異常を認 めることができなかつた。

以上まとめると，

1）中等度貧血があり，血清鉄は $49 \gamma / \mathrm{dl}$ と低值 である。

2）血液生化学で総コレステロール $262 \mathrm{mg} / \mathrm{dl}$ と 高值である。

3）身体計測では 8 才，骨年令で 5 才に相当す る。

4）I Q78と精神薄弱に近いが学業は中等度で 高校まで進み，いちじるしい知能障害はない。し かし，脳波に軽度の異常が認められている。

5）甲状腺機能は原発性の機能低下を示し，甲 状腺そのものの発生異常が認められる。

6）その他の内分泌機能はほぼ正常であるが，

表1，焎者と乙の家族の梌查所見

\begin{tabular}{|c|c|c|c|c|c|c|c|}
\hline & & 婁 者 & 父 & 母 & 兄 & 姑 A & 姉 B \\
\hline 身 & 長 $\mathrm{cm}$ & 120.9 & 165.0 & 150.0 & 178.0 & 150.0 & 145.0 \\
\hline 体 & 重 $\mathrm{kg}$ & 29.0 & 58.0 & 43.0 & & 48.0 & 41.5 \\
\hline 現 & 在 & 体霜症 & 健康 & 健康 & 健康 & 健康 & 精神障害 \\
\hline \multirow{2}{*}{ 甲 } & BMR $\%$ & $*+3$ & & & -4 & -8 & -15 \\
\hline & PBI $\gamma / \mathrm{dl}$ & 1.0 & & 5.8 & & 2.6 & 1.7 \\
\hline \multirow{2}{*}{$\begin{array}{l}\text { 状 } \\
\text { 腺 }\end{array}$} & $\begin{array}{l}\text { I I uptake } \\
\text { (24洔間) } \%\end{array}$ & 2.4 & & 17.2 & 11.0 & 10.0 & 1.0 \\
\hline & $\begin{array}{l}\mathrm{T}_{3} \text { resin } \\
\text { uptake } \%\end{array}$ & 23.6 & 29.1 & 28.4 & 28.0 & 37.6 & 27.0 \\
\hline \multirow{2}{*}{$\begin{array}{l}\text { 機 } \\
\text { 能 }\end{array}$} & $\begin{array}{l}\text { T. choles- } \\
\text { terol } \mathrm{mg} / \mathrm{dl}\end{array}$ & 262 & 180 & 216 & & 190 & 214 \\
\hline & Scintigram & $\begin{array}{c}\text { Sublingual } \\
\text { thyroid }\end{array}$ & 正常 & 正常 & 正常 & $\begin{array}{l}\text { Sublingual } \\
\text { thyroid }\end{array}$ & $\begin{array}{l}\text { Sublingual } \\
\text { thyroid }\end{array}$ \\
\hline
\end{tabular}

*糜年で計算したもの

骨年令 $(5$ 才 $)-25.5 \%$

身体年令 $(8$ † $)-20.0 \%$ となつてる。 
原発性無月経がある。

家族歴；母方の家系に双生児が 2 対認められ る、すなおち，患者の祖父は双生児の一方であ り，また患者の母親の叔父が双生児である。しか し，父母両家系に甲状腺疾患を思和せるものはな く，また血族結婚もみとめられない，患者は 5 人 兄弟峬妹の末子であり，3名の姉のらち長女は生 後 2 カ月で死亡（死因不明）している。下 2 名の 姉は互いに一卵性双生児である。姉 $\mathrm{A}$ は外見上全 く健康であるが，姉 B は18才の時に関係妄想が出 現, 以後精神分裂症として治療をらけていた。し かし,臨床的に身長 $145 \mathrm{~cm}$, 皮膚は貧血様かつ乾燥 して荒く，また頭髮は濃く乾燥して拈り，月経不 順を認める。また趾反射でアキレス腱反射の民り が遅いことなどから甲状腺機能低下症を示した。 さらに甲状腺機能検査で機能低下の所見がえら れ，最近，甲状腺機能低下に上る精神障害である と考えられている．兄は全く健康である．表1に みられるごとく患者の両親は正常と考克られるが 同胞の双生児の姉たちは，AはBにやや体格で隹 つている。また臨床的にも検查所見でも甲状腺機 能は正常範囲に入つている，姉Bについてはその 他の検査で, 尿中17-KS $6.4 \mathrm{mg} / \mathrm{day}$, growth hormone早朝空腹時 $1.5 \mathrm{~m} \mu \mathrm{g} / \mathrm{ml}$, insulin 負荷 ( 0.1

表 2 . Urinary excretion of ${ }^{231}$ I labeled L-diiodotyrosine (LD $\left.{ }^{131} I T\right)$ after intravenous administration.

\begin{tabular}{c|c|c|c}
\hline \multirow{2}{*}{ subject } & \multicolumn{2}{|c}{ \%labeled iodine in urine as $\mathrm{LD}^{131} \mathrm{IT}$} \\
\cline { 2 - 4 } & \multicolumn{2}{|c}{ collection period, hs } \\
\cline { 2 - 3 } & $0 \sim 1$ & $1 \sim 2$ & $2 \sim 4$ \\
\hline normal & 15.36 & 7.09 & 4.17 \\
\hline 患 者 & 14.5 & 7.1 & 2.1 \\
\hline 每 親 & 26.1 & 12.1 & 6.6 \\
\hline 姉 A & 37.1 & 32.0 & 27.9 \\
\hline 姉 B & 28.3 & 17.6 & 11.5 \\
\hline
\end{tabular}

* T. Kusakabe and T. Miyake.: J. clin. Endocr. 上り.
単位 $/ \mathrm{kg}) 30$ 分後 $5.0,60$ 分後 $6.0,90$ 分後 1.0 .

A C T Hテストでは前 $0.8 \mathrm{mg} / \mathrm{day}$ ，40単位筋 注で 1 日目 $5.2,40$ 単位追加 2 日目 $5.55,3$ 日目 5.48 といら值が党られている。ささらに本家系につい $\tau,{ }^{131}$ I標識diiodotyrosine静注投与後の尿中D ${ }^{131}$ I 排泄量をみると表 2 に見られるごとく，母親と 2 名の姉については，正常人の尿中排泄\%より多い という結果をえた。患者ではほぼ正常の値であつ た。姉Bについては患者之同様に ${ }^{131}$ 標識thyroxi一 $\mathrm{ne}\left(\mathrm{T}_{4}{ }^{131} \mathrm{I}\right)$ 静注投与後の血清 $\mathrm{T}_{4}{ }^{131} \mathrm{I}$ の測定から， その崩壊状態をみたところ $\mathrm{T}^{1} / 2$ が 6.5 日， daily volume turn over $40.7 \gamma /$ day $と \mathrm{~T}_{3}$ で治療中であ るためかほぼ正常の值がえられた。

\section{考案}

本例が甲状腺の発生異常を伴なら原発性甲状腺 機能低下症であることは，以上のべて来たことか らも明らかである. sporadic non-goitrous cretin の範鱚に入るものと考えられる。また成長の障害 は諸検查成績から甲状腺機能低下によるものであ ることは確かである。とくに宷牙，骨の発育障害 等にはつきりあらわれている。つぎに以下いくつ かの点について考察を行なつてみたい。

1.甲状腺は，胎生期第 3 週に咽頭上部の腹壁 上皮から突出した原基が甲状腺結節となり漸次下 降し, 胎生第 4 週に両側方に膨隆し両葉を形成し 中央部は陕部を形成する。下降の際に，心臟，大 血管の下降と变位に関連し, 正常の第一気管軟骨 輪の高さをとらずに種々の高さに来ることがあ り，舌下部甲状腺もその例であると考克られる。 機能低下症や王迫症状の出てこない正常人での甲 状腺の位置異常がどのくらいの頻度であるかる知 ることは困難であり，偶然の機会に発見されるく らいであるう。

2. 本症例が原発性甲状腺機能低下に上る侏儒 症であることは確かであるが，甲状腺の位置異常 とそのホルモン産生能力の障害とは, 舌根部甲状 腺や胸腔内甲状腺が発見される端緹が，その機 能低下ではなく，むしろ圧迫症状であることが多 いことからも，必ずしも立行寸るものではないと 
考えられる ${ }^{3)}$ 。散発性非甲状腺腫性クレチン35例 について，シンチグラムで調べた Garbの報告に よるとathyrosis18例 $(51 \%)$, dysgenesis 9 例 (26 $\%$ ), maldescent 8 例 (23\%) であり, 本例はmaldescentに該当する必のと思わ礼る4． maldescent に入るものは, 他のgroupに抏てては, 男女の出現 率が泳涪同じであるのに，圧倒的に女子に多く， 甲状腺シンチグラムを利用した舌下部甲状腺の報 告例19例（1953年～1959年まで）のうち16例が女 性であること，さらに Neel，Carrらの54例の報告 を検討しても女性に多いことは確かでするらと考 えられる光275)。

3.甲状腺腫性クレチンが家族的に出現するこ とは上く知られており，このことはその病因が多 分に遗伝学的問題を含んでいることを考克させる $か^{3} 3^{126)}$ ，非甲状腺腫性クレチンが家族的に出現す ることはまれとされており，血族結婚のある家系 飞, 時にみられる゙。 Warkanyらに上れば，一卵性 双生児の一方のみにクレチンを生じた例があり， 報告者らは遺伝的原因よりは，母親の妊娠時の身 体状況にその病因を求めている゙，Warkanyの例 は母親は妊娠時に甲状腺機能低下の状態にあり， また本患者之同様母方の家系に 2 対の双生児がみ とめられていることは興味深い。

4.甲状腺腫性の機能低下症についてはその木 ルモン産生過程における先天的異常が見出され， その病因の説明も，遗伝的に受継がれた先天的代 謝障害であることが次第に明らかにされているの であるが6>8/9)10〉，本例のごと〈甲状腺腫のない発 生異常によるクレチンの病因についてはこれむで 子明らかでないことが多い。しかし，本患者，ま たその家族について全身性の脱ヨード酵素の異常 を思わせる所見を考觉ると，やはり本例において は先天性の代謝障害が存在するのではないかと推 定される。ささらに，この代謝障害が甲状腺組織が 正常に発生しなかつたことと関連していることも 考无られる ${ }^{3}$.

5.甲状腺組織の発生を妨げる因子は依然明ら かでないが，本例のごとく，雨親，またその家系
に全く異常は見出されてないが，その子供に突然 発生し，かつ同胞女子に多く出現していること は, 母親の娃娠時の状況が重要な因子であると思 われるが，一卵性双生児の双方に異常が出現して いることを考台合せると遺伝的な因子も考慮すべ きであると考光られる1 患, トキップラスマ症などの感染症, 橋本病など の自己兔疫疾患之考克ら机ている病気などが考光 られるが，本例では現在までの検索のところその ような原因的事項は見当らない。

6. ホルモン欠乏による症状発現については， 甲状腺の発生が妨げられ，その結果ホルモン産生 過程に障害が起こればホルモンの欠乏状態が発生 する。胎児期, 出産後の成長に必要な甲状腺ホル モン量とホルモン産生可能な甲状腺組織が，その 量に応じきれなくなつたときに症状があらわれて 来るものと考学られる3゙。 したがつて胎生期にす でに不足，または欠如してい狆，生下時すでに 甲状腺機能低下の状態を示し，また生後气の成長 に従つて不足が起こつて来机ば，その時に症状が 出るものと考学られる。本例においては，生後間 もなく甲状腺機能低下の存在を思わせる症状が認 められているが, 知能の発達がいちじるしくは侵 されていない点，また，甲状腺がわずかながら181I を恸取する点より，甲状腺ホルモンの矢如は完全 でなく，ある程度のホルモン分泌が行なわれてい たものと思われる。

以上，いずれにしても本例のごとき甲状腺発生 異常に上る原発性甲状腺機能低下症に伴なら侏需 症に拈いて，

1）甲状腺が何故に正常に発生しえなかつたの か.

2）甲状腺の発生が正常でなかったことが，何 故そのホルモン産生能に障害を起こしたのか。

3）ホルモンを全く産生しないことはない点か ら，産生過程は正常人のそれと同じなのか。 等が問題として今後も残されると思う。したがつ て同様症例方多数集妨机, 遗伝的, 発生学的, 生化学的に解明されることが期待される。 
なお本患者は，診断確定後 triiodothyronine 30 r/dayに上る治療を開始し，約 1 力月の経過で， 顔貌, 腹部膨隆, 健反射の正常化, 血清コレステ ロールの低下，BMRの著明な上昇がみられ，現 在も外来的に経過観祭中である。

\section{文献}

1)J.V. Neel, E.A. Caar, W.H. Beierwaltes, and R.T. Davidson: Genetic Studies on the congenitally Hypothyroid. Pediatrics, $27: 269,1961$. 2)E.A. Carr, W.H. Beierwaltes, J.V. Neel, R.T. Davidson, G.H. Lowrey, V.N. Dadson, and J.H. Tanton: The various types of thyroid malfunction in cretinism and their relative frequency. Pediatrics, $28: 1,1961$. -3)E.M. McGirr and V.H. Hutchinson: Dysgenesis of the thyroid gland as a cause of cretinism and juvenile myxedema. J. clin. Endocr., 15 : 668, 1955. -4)M. Garb: The role of thyroid dysgenesis and maldescent in the etiology of sporadic cretinism. J. Pediat., $60: 830$, 1962. -5)H.J. Andersen: Studies on Hypothyroidism in Children. Suppl. 125, Acta paediat, $50: 50$, 1961. -6)J.H. Hutchinson, E.M. McGirr: Hypothyroidism as an inborn error of metabolism. J. clin. Endocr., $14: 869,1954$. -7)J. Warkany and T.K. Selkirk: Discordant monozyygotic Twins. Amer. J. Dis. Child., 89 : 144, 1955. -8)J.B. Stanbury and A. Querido: Genetic and environmental Factors in cretinism: a classification. J. clin. Endocr., 16 : 1522, 1956. -9) J.B. Stanbury, J.W.A. Meijer and A.A.H. Kassennaar: The Metabolism of iodotyrosine. The Metabolism of mono- and di-iodotyrosine in certain patients with familial goitre. J. clin. Endocr., 16 : 848, 1956. -10) R.H. Parker and W.H. Beierwaltes: Inheritance of Defective Organification of iodine in familial goitrous cretinism. J. clin. Endocr., $21: 21,1961$. 